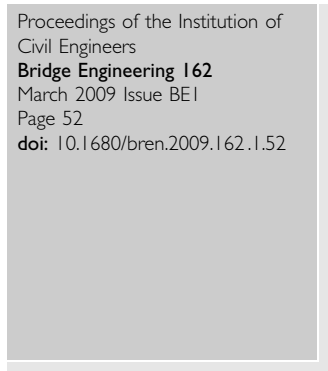

\title{
Bridge Engineering: Referees for 2008
}

The following is a list of referees who have reviewed papers for Bridge Engineering between 1 January 2008 and 31 December 2008. The Institution of Civil Engineers is very grateful for their assistance.

We are continually looking for suitable reviewers for papers submitted to Bridge Engineering Papers published in the Proceedings of the ICE must be submitted to at least two independent referees to judge accuracy, style, impact, importance and interest.

If you are interested in reviewing articles on any topic related to engineering and computational mechanics, please submit your name, qualifications or CV, and areas of expertise. We are in need of individuals who will agree to review papers in a timely fashion (within 3 to 4 weeks of receipt) and provide confidential feedback to the Editorial Advisory Panel concerning the quality of the paper and any suggested revisions that would be appropriate.

If you are such a person, please contact Agnes Alvite (tel: 0207665 2204; e-mail: agnes.alvite@ice.org.uk) for more information on the referee process.

Dr Jose Adam

Ph.D. Muhammed Akiner

Dr Ghassan Al-Chaar

Mr Andrew Alder

Professor Mark Alexander

Dr Daniel Anstice

Dr Brahim Benmokrane

Mr Graham Bessant

Mr Ipsa Biana

Professor Franco Bontempi

Mr. Danny Boothman

Mr Gerard Brennan

Professor Colin Brown

Mr J N Carpenter

Professor Kuo-Chun Chang

Mr Gordon Clark

Mr Charles Cocksedge

Mr. Graham Cole

Mr. Barry Colford

Mr David Collings

Mr David Cooper

Mr Jeremy Cutter

Dr Roger Dixon
Professor George England

Mr J Evans

Dr Jeffrey Fisher

Mr John Fleck

Mr Malcolm Fletcher

Dr Matthew Gilbert

Dr Paul Greening

Mr Christopher Hendy

Mr Gareth Hughes

Mr David Iles

Dr Paul A Jackson

Professor Roger Johnson

Mr Ted Kay

Dr Yail Kim

Mr T Kitada

Dr Risto Kiviluoma

Dr Robert Lark

Professor Kincho Law

Mr Chris Levy

Professor Adrian Long

Mr Angus Low

Professor Jerome Lynch

Dr John Ma
Mr Barry Mawson

Professor Ian May

Mr Walter McQueen

Dr Devdas Menon

Prof Pilate Moyo

Professor Eugene 0'Brien

Dr Alan 0'Connor

Dr Brent Phares

Dr Alexander Rabinovich

Mr John Redpath

Professor Ken Reinschmidt

Reviewer First Reviewer Last

Title Name Name

Mr Martin Roach

Professor Mehmet Saka

Mr David Searle

Mr Charles Slater

Mr David Smith

Uwe Starossek

Dr S Uren

Mr Bill Valentine

Mr Giles Waley 